\title{
BIO_ALGAE 2: improved model of microalgae and bacteria consortia for wastewater treatment
}

\author{
Alessandro Solimeno $^{1}$ (D) - Cintia Gómez-Serrano ${ }^{1}$. Francisco Gabriel Acién ${ }^{1}$
}

Received: 11 January 2019 / Accepted: 24 June 2019

(C) Springer-Verlag GmbH Germany, part of Springer Nature 2019

\begin{abstract}
A new set up of the integral mechanistic BIO_ALGAE model that describes the complex interactions in mixed algal-bacterial systems was developed to overcome some restrictions of the model. BIO_ALGAE 2 includes new sub-models that take into account the variation of microalgae and bacteria performance as a function of culture conditions prevailing in microalgae cultures $(\mathrm{pH}$, temperature, dissolved oxygen) over daily and seasonal cycles and the implementation of on-demand dioxide carbon injection for $\mathrm{pH}$ control. Moreover, another aim of this work was to study a correlation between the mass transfer coefficient and the hydrodynamics of reactor. The model was calibrated using real data from a laboratory reactor fed with real wastewater. Moreover, the model was used to simulate daily variations of different components in the pond (dissolved oxygen, $\mathrm{pH}$, and $\mathrm{CO}_{2}$ injection) and to predict microalgae $\left(X_{\mathrm{ALG}}\right)$ and bacteria $\left(X_{\mathrm{H}}\right)$ proportions and to estimate daily biomass production $\left(C_{\mathrm{b}}\right)$. The effect of $\mathrm{CO}_{2}$ injection and the influence of wastewater composition on treatment performance were investigated through practical study cases. $X_{\mathrm{ALG}}$ decreased by $38 \%$, and $X_{\mathrm{H}}$ increased by $35 \%$ with respect to the system under $\mathrm{pH}$ control while microalgae and bacteria proportions are completely different as a function of influent wastewater composition. Model simulations have indicated that $C_{\mathrm{b}}$ production $\left(\sim 100 \mathrm{gTSS} \mathrm{m}^{-3}\right.$ day $^{-1}$ for manure and centrate) resulted lower than $C_{\mathrm{b}}$ production obtained using primary influent wastewater $\left(155 \mathrm{gTSS} \mathrm{m}^{-3}\right.$ day $\left.^{-1}\right)$.
\end{abstract}

Keywords Microalgae $\cdot$ Bacteria $\cdot$ Wastewater treatment $\cdot M \cdot$ Nitrogen removal $\cdot$ Phosphorus removal

\section{Introduction}

Microalgae-based technologies for wastewater treatment were proposed in the 1960s by Oswald, but till now, they are not fully exploited at industrial scale. Only recently, these technologies are being improved to accomplish requirements of industry, thus reducing the hydraulic retention time, and accomplishing regulation in quality of water release among others. Industry is interested on microalgae-based technologies due to the potential total cost savings, including in

Responsible editor: Gerald Thouand

Electronic supplementary material The online version of this article (https://doi.org/10.1007/s11356-019-05824-5) contains supplementary material, which is available to authorized users.

Alessandro Solimeno

solimeno.ale@gmail.com

1 Department of Chemical Engineering, University of Almería, Ctra. Sacramento, s/n, La Cañada de San Urbano, 04120 Almeria, Spain electrical power, with respect to conventional systems and to recover nutrients contained into wastewater (Lundquist et al. 2010; Craggs et al. 2013; Suganya et al. 2016). Thus, industry is moving from highly resources demanding "standard wastewater treatment plants" to sustainable "resource recovery plants," which are able to purify water and produce microalgae biomass suitable to obtain by-products or including energy (Chisti 2007; Brennan and Owende 2010). In this regard, microalgae-based wastewater treatment systems represent an opportunity to replace conventional sanitation systems with "productive industry." Although microalgae produced with wastewaters cannot be used for direct human applications, it can be useful to produce animal feed, biofertilizers, bioplastics, and including bioenergy (Spolaore et al. 2006; Acien et al. 2013).

In microalgae-based wastewater treatment processes, consortia of different microalgae species and bacteria always prevail (Acien et al. 2016). Phenomena taking place in these consortia are highly variable as a function of reactor hydrodynamic, wastewater characteristics, and operation conditions. Most of these phenomena take place with different time scale 
and interdependent (García et al. 2006). Moreover, microalgae and bacteria reactions change with time due to the daily variation of environmental variables such as solar radiation and temperature, in addition to operation variables such as hydraulic retention time (HRT), nutrients concentrations, and organic load present in the influent wastewater. To design properly microalgae-based wastewater treatment processes, it is necessary to develop complete models integrating the physicalchemical and the biological phenomena taking place in these systems, analogous to the design of activated sludge based conventional wastewater treatment processes.

On this sense, whereas different IWA (International Water Association) models have been developed for conventional wastewater treatment systems, a lack of models integrating the role of microalgae on wastewater treatment processes exists. Dissolved oxygen concentration and $\mathrm{pH}$ variations in microalgae photobioreactors are largely different from conventional activated sludge systems; thus, the performance of bacteria at these conditions must be also reanalyzed. Robust mechanistic models for microalgae based wastewater treatment systems are required to better understand microalgae-bacteria interactions, optimize the design, and control the performance of the system. The use of mathematical model represents a powerful tool to overcome the bottlenecks of this eco-technology. In the last decade, several microalgae-bacteria models were developed to predict microalgae biomass production (Buhr and Miller 1983; Reichert et al. 2001; Sah et al. 2011). One general limitation of these models is not to combine the overall biochemical processes involved in these systems and the simultaneous effects of light intensity, temperature, $\mathrm{pH}$, or the effect of high dissolved oxygen (DO) concentration on biomass growth (Solimeno et al. 2017a).

Recently, the new dynamic model BIO_ALGAE (Solimeno et al. 2017a) was developed with the objective to become the most fundamental basis for modelling approach that integrates biokinetic, chemical, and physical processes that occur in microalgae systems. With respect to previous microalgae-bacteria models (Buhr and Miller 1983; Reichert et al. 2001; Sah et al. 2011), BIO_ALGAE model includes inorganic carbon as a limiting substrate for the growth of microalgae and processes depending on temperature, $\mathrm{pH}$ dynamics, oxygen concentrations, light attenuation, and the transfer of gases to the atmosphere. The model was calibrated and validated in a pilotscale raceway reactor, and it was suitable to predict daily variations of the main components in this system (Solimeno et al. 2017a). After that, the model was validated in a long-term scale in order to predict seasonal variations of microalgae and bacteria biomass and the effect of different HRT operating strategies on system performance (Solimeno and García 2019).
In this paper, we want to overcome some restrictions of the BIO_ALGAE model (Solimeno et al. 2015, 2017a, 2017b), including new sub-models that consider the variation of microalgae and bacteria performance as a function of culture conditions prevailing in microalgae cultures ( $\mathrm{pH}$, temperature, dissolved oxygen) over daily and seasonal cycles and to find a correlation between the mass transfer coefficient and the hydrodynamic of reactor. Moreover, other relevant feature of the new model is the implementation of on-demand carbon dioxide $\left(\mathrm{CO}_{2}\right)$ injection for $\mathrm{pH}$ control. For this, the new model BIO_ALGAE 2 was implemented and calibrated using real data from a laboratory reactor fed with real wastewater. Furthermore, the model was used (1) to analyze the effect of $\mathrm{CO}_{2}$ injection on the performance of the systems (biomass production, chemical oxygen demand removal, and nutrient uptake) and (2) to study the influence of wastewater composition on treatment performance.

\section{Materials and methods}

\section{Photobioreactor and culture conditions}

Experimental data were obtained in four stirred tank reactors (cylindrical-type 10.4-cm diameter and 16.5-cm height with 1400-ml capacity) provided by magnetic stirrers with a rotation speed of $400 \mathrm{rpm}$ that ensures perfect mixing conditions. The reactors were inoculated with $700 \mathrm{ml}$ culture of Scenedesmus sp. previously adapted for 2 weeks to wastewater, under controlled $\mathrm{pH}(8.0)$ and temperature $\left(25.0^{\circ} \mathrm{C}\right)$ in a 2 1 bubble column reactor, and completed with $700 \mathrm{ml}$ of primary wastewater (WWTP) obtained daily by decanter from a municipal wastewater treatment plant located in El Ejido, Almeria (Spain). After 4 days, the reactors are operated in continuous mode at 0.2 day $^{-1}$, under controlled $\mathrm{pH}$ at 8.0 by on-demand injection of pure $\mathrm{CO}_{2}$ at $0.01 \mathrm{l} \mathrm{min}^{-1}$ and temperature at $25{ }^{\circ} \mathrm{C}$ by controlling the temperature of the room where the reactors are located. Light was artificially provided using eight fluorescent tubes of $28 \mathrm{~W}$ (Philips Daylight T5), simulating daily light/dark circadian cycle. The maximal irradiance calculated inside the reactors in the absence of cells was $1850 \mu \mathrm{E} \mathrm{m}^{-2} \mathrm{~s}^{-1}$.

To monitor the reactors DO, $\mathrm{pH}$ and temperature probes (Crison Instruments, Spain) connected to a control-transmitter unit MM44 (Crison Instruments, Spain) were installed and connected to a PC for data acquisition and control purposed. Software for control and data acquisition was developed in DaqFactory 5.0 (Azotech Inc.). Additionally irradiance values inside the reactors were determined using a spherical quantum sensor SQS-100 Walz GmbH (Effeltrich, Germany). Data used for model calibration were obtained in continuous mode for eight consecutive days during steady state. 


\section{Analytical methods}

Samples of influent wastewater and the outlet of the respective reactor were periodically monitored to determine the concentration of ammonium $\left(\mathrm{gN} \mathrm{m}^{-3}\right)$, nitrate $\left(\mathrm{gN} \mathrm{m}^{-3}\right)$, phosphorous $\left(\mathrm{gP} \mathrm{m}^{-3}\right)$, total inorganic carbon (TIC, $\mathrm{gC} \mathrm{m}^{-3}$ ), chemical oxygen demand (COD, $\mathrm{gO}_{2} \mathrm{~m}^{-3}$ ), and total suspended solids or biomass $\left(C_{\mathrm{b}}\right.$, gTSS m$\left.{ }^{-3}\right)$. Ammonium was determined by the Nessler reactive method. Nitrate was quantified using a spectrophotometer at 220 and $275 \mathrm{~nm}$ (Standard methods for the examination of water and wastewater, 2017). Phosphorus was determined by phosphovanado-molybdate method in conjugation with UV-visible spectrophotometer. Total inorganic carbon (TIC) was quantified by a titrimetric analysis adding sulfuric acid $0.01 \mathrm{~N}$ in $\mathrm{pH} 8.3$ carbonates with $1 \%$ phenolphthalein and $\mathrm{pH} 4$ bicarbonates with $1 \%$ methyl orange (Bisutti et al. 2004). The dry weight biomass concentration $\left(C_{\mathrm{b}}\right)$ was measured by filtering $50 \mathrm{ml}$ of cell past through $0.45-\mu \mathrm{m}$ filters and drying it in an oven set at $80^{\circ} \mathrm{C}$ for $24 \mathrm{~h}$. Hach-Lange kits spectrophotometer (LCK-555, LCI-400) was used to determine the amount of COD concentrations of the inlet WWTP and at the outlet of the photobioreactors.

\section{Model implementation}

BIO_ALGAE 2 model, based on BIO_ALGAE model (Solimeno et al. 2017a), was used to perform simulations. The model describes biokinetic reactions by relating the growth rate to the availability of nutrients in the medium using Monod formulation. Instead of Droop formulation, which accounts the luxury uptake and storage of nutrients for later growth, Monod formulation is more properly in this study because in wastewater systems, which are generally rich in nutrients, using external nutrient-limiting concentrations makes it easier for them to be measured and known, and it guarantees enough modelling accuracy (Solimeno and García 2019).

A detailed description of the processes, parameters, and coefficients used to perform simulations was introduced in Supplementary data (SD) for better understanding the mechanistic model BIO_ALGAE (Tables S1, S2, S3, S4, and S5). Each processes and mathematical expressions were implemented in COMSOL Multiphysics ${ }^{\mathrm{TM}}$ v5.3 simulation software. Photobioreactor geometry has been streamline in a $0 \mathrm{D}$ domain to better suit the entire volume of the used reactors and to allow a significant reduction of computational complexity. This simplification stems from the fact that the reactors were designed to guarantee perfect mixing; thus, each point of culture medium fits the same physical, chemical, and biokinetic characteristics.

A cardinal $\mathrm{pH}$ sub-model was included to represent the inhibitory effects on the growth response of microalgae and bacteria at elevated $\mathrm{pH}$ (Sutherland et al. 2014). The cardinal $\mathrm{pH}$ sub-model is based on the cardinal temperature model (CTMI) presented by Bernard and Rémond (2012). Instead of temperature values, the model contains three values of $\mathrm{pH}$ $\left(\mathrm{pH}_{i, \text { max }}, \mathrm{pH}_{i, \text { min }}\right.$ and $\left.\mathrm{pH}_{i, \mathrm{opt}}\right)$, where $i$ is the $i$ th species of microorganism and was used to describe the effects of $\mathrm{pH}$ on microalgae, heterotrophic, and nitrifier bacteria growth. The function $\varphi(\mathrm{pH})(-)$, representing the influence of $\mathrm{pH}$, is given by following general Eq. (1):

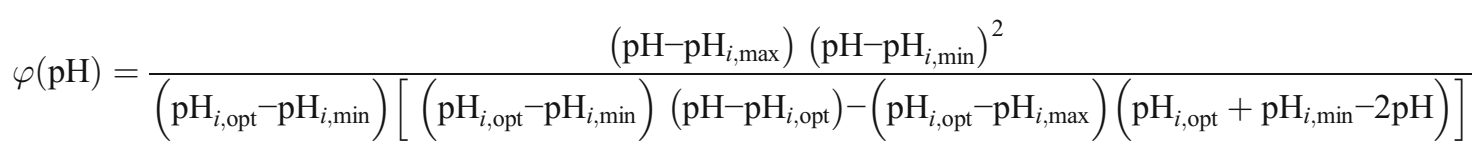

where $\mathrm{pH}_{i, \min }$ and $\mathrm{pH}_{i, \max }$ represent the lower and higher limits that each microorganism can support. Below and above this range, the growth of microorganisms is assumed to be 0 . The function $\varphi(\mathrm{pH})$ is maximum at $\mathrm{pH}_{i, \mathrm{opt}}$. The value of the characteristic parameters $\left(\mathrm{pH}_{i, \max }, \mathrm{pH}_{i, \text { min}}\right.$, and $\left.\mathrm{pH}_{i, \mathrm{opt}}\right)$ was evaluated by a non-linear regression of the experimental values obtained for each type of microorganism (Scenedesmus sp., heterotrophic and nitrifier bacteria) (Table S6a, in SD). Likewise, a cardinal temperature sub- model was also implemented replacing the normal distribution of the thermic photosynthetic factor $\left(f_{\mathrm{T}, \mathrm{FS}}\right)$ which describes microalgae growth temperature dependency (Solimeno et al. $2015)$ and the Arrhenius equation of the thermal factor $\left(f_{\mathrm{T}, \mathrm{MB}}\right)$ which describes the temperature dependence of nitrifier bacteria (Langergraber et al. 2009; Reichert et al. 2001; Sah et al. 2011; Solimeno et al. 2017a) (Eq. 2).

$\varphi(T)=\frac{\left(T-T_{i, \text { max }}\right)\left(T-T_{i, \min }\right)^{2}}{\left(T_{i, \mathrm{opt}}-T_{i, \min }\right)\left[\left(T_{i, \mathrm{opt}}-T_{i, \min }\right)\left(T-T_{i, \mathrm{opt}}\right)-\left(T_{\mathrm{i}, \mathrm{opt}}-T_{i, \max }\right)\left(T_{i, \mathrm{opt}}+T_{i, \min }-2 T\right)\right]}$ 
where $T_{i, \min }$ and $T_{i, \max }$ represent the lower and higher limits. Below and above this range, the growth of microorganisms is assumed to be 0 . The function $\varphi(T)$ is maximum at $T_{i, \text { opt }}$. In the same way of the $\mathrm{pH}$ values, the value of characteristic parameters $\left(T_{i, \max }, T_{i, \min }, T_{i, \text { opt }}\right)$ was evaluated by a nonlinear regression of the experimental values obtained for Scenedesmus sp. and nitrifier bacteria. These values are shown in Table S6b. Figure S1 in SD shows the experimental values and the non-linear regression from which the values for $T_{i, \max }$, $T_{i \text {,min }}$, and $T_{i, \text { opt }}$ were retrieved. The cardinal temperature submodel was not adaptable for heterotrophic bacteria, which is described by the thermal factor $\left(f_{\mathrm{T}, \mathrm{MB}}\right)$. This factor follows Arrhenius equation increasing exponentially with temperature $\left(T,{ }^{\circ} \mathrm{C}\right)$ (Reichert et al. 2001; Solimeno et al. 2017a):

$f_{\mathrm{T}, \mathrm{MB}}(T)=\theta^{T-T_{\mathrm{H}, \mathrm{ppt}}}$

where $T_{\mathrm{H}, \mathrm{opt}}$ is the optimal temperature for heterotrophic bacteria and $\theta$ is the temperature coefficient (Table S6b). Another new important feature added to the BIO_ALGAE model was the implementation of $\mathrm{CO}_{2}$ injection for both $\mathrm{pH}$ control and carbon supply. In our experiments, the culture medium was not limited by carbon; thus, $\mathrm{CO}_{2}$ injection is used to keep $\mathrm{pH}$ below 8.0 (Eq. 4).

$\mathrm{CO}_{2 \text { inj }}=\left\{\begin{array}{cc}\mathrm{CO}_{2}^{*}, & \mathrm{pH} \geq 8 \\ 0, & \mathrm{pH}<8\end{array}\right.$

where $\mathrm{CO}_{2} *$ is the flow rate of pure $\mathrm{CO}_{2}\left(\mathrm{~min}^{-1}\right)$.

\section{Calibration procedure}

Influent WWTP concentrations observed at beginning of the experiment were used as constant input values to run simulations (Tables 1 and 2). Measurements of particulate organic components of inlet COD are very complicated. Accordingly with recommended values by Henze et al. (2000), fraction of COD influent was defined as follows: $22 \% \mathrm{~S}_{\mathrm{S}}$ (readily biodegradable soluble organic matter), $50 \% X_{\mathrm{S}}$ (slowly biodegradable particulate organic matter), $10 \% \mathrm{~S}_{\mathrm{I}}$ (inert soluble organic

Table 1 Influent WWTP parameters during the 8 days considered for calibration

\begin{tabular}{ll}
\hline Parameters & Influent WWTP \\
\hline $\mathrm{COD}_{\mathrm{TOT}}\left(\mathrm{gO}_{2} \mathrm{~m}^{-3}\right)$ & 535 \\
$\mathrm{NH}_{4}-\mathrm{N}\left(\mathrm{gN} \mathrm{m}^{-3}\right)$ & 35.5 \\
$\mathrm{NO}_{3}-\mathrm{N}\left(\mathrm{gN} \mathrm{m}^{-3}\right)$ & 4.44 \\
$\mathrm{PO}_{4}-\mathrm{P}\left(\mathrm{gP} \mathrm{m}^{-3}\right)$ & 10.32 \\
$\mathrm{TIC}\left(\mathrm{gC} \mathrm{m}^{-3}\right)$ & 119 \\
\hline
\end{tabular}

$\mathrm{S}_{\mathrm{S}}, X_{\mathrm{S}}, X_{\mathrm{H},} X_{\mathrm{I}}, X_{\mathrm{AOB}}$, and $X_{\mathrm{NOB}}$ influent concentrations were estimated from $\mathrm{COD}_{\mathrm{TOT}}$ concentration (see text)
Table 2 Influent water concentrations of centrate and manure

\begin{tabular}{lll}
\hline Parameters & Influent centrate & Influent manure \\
\hline $\mathrm{COD}_{\mathrm{TOT}}\left(\mathrm{gO}_{2} \mathrm{~m}^{-3}\right)$ & 371 & 840 \\
$\mathrm{NH}_{4}-\mathrm{N}\left(\mathrm{gN} \mathrm{m}^{-3}\right)$ & 156 & 467 \\
$\mathrm{NO}_{3}-\mathrm{N}\left(\mathrm{gN} \mathrm{m}^{-3}\right)$ & - & 11 \\
$\mathrm{PO}_{4}-\mathrm{P}\left(\mathrm{gP} \mathrm{m}^{-3}\right)$ & 24 & 5 \\
$\mathrm{TIC}\left(\mathrm{gC} \mathrm{m}^{-3}\right)$ & 173 & 490 \\
\hline
\end{tabular}

$\mathrm{S}_{\mathrm{S}}, X_{\mathrm{S}}, X_{\mathrm{H}}, X_{\mathrm{I}}, X_{\mathrm{AOB}}$, and $X_{\mathrm{NOB}}$ influent concentrations were estimated from $\mathrm{COD}_{\mathrm{TOT}}$ concentration (see text)

matter), $8 \% X_{\mathrm{I}}$ (inert particulate organic matter), and $10 \% X_{\mathrm{H}}$ (heterotrophic bacteria). Particulate and organic matter concentrations are expressed in grams of COD per cubic meter in all IWA models. In the present work microalgae, bacteria and organic matter biomass are transformed from COD to TSS (total suspended solids) assuming a ratio $\mathrm{COD} / \mathrm{TSS}=0.80$ (Khorsandi et al. 2014) in order to compare experimental and simulation results. Water temperature varied between 25.3 and $29.5{ }^{\circ} \mathrm{C}$ and the PAR ranged from 0 and $1850 \mu \mathrm{mol} \mathrm{m}{ }^{-2} \mathrm{~s}^{-1}$.

The culture medium concentration when the reactor was operated in continuous mode is described in Table 3. Unfortunately, the concentration of each particulate component $\left(X_{\mathrm{ALG}}, X_{\mathrm{S}}, X_{\mathrm{I}}, X_{\mathrm{H}}, X_{\mathrm{AOB}}\right.$, and $\left.X_{\mathrm{NOB}}\right)$ in the culture medium was not known. Therefore, the initial ratio of particulate components needed to estimate concentrations was established from the TSS (assumed to be as the sum of $X_{\mathrm{ALG}}, X_{\mathrm{S}}, X_{\mathrm{I}}, X_{\mathrm{H}}, X_{\mathrm{AOB}}$, and $X_{\mathrm{NOB}}$ ) value based on previous works (Solimeno et al. 2017a). Fifteen additional parameters from both temperature and $\mathrm{pH}$ cardinal sub-models were added to the 93 parameters describing microalgae, bacteria, and physical and chemical processes (Solimeno et al. 2017a; Solimeno and García 2019) for a total 108 parameters (Tables S3-S4, SM).

Based on previously uncertainty analysis (Solimeno et al. 2016, 2017a), the model was calibrated by adjusting only the parameters related to the transfer of gases to the atmosphere $\left(K_{1} a_{, \mathrm{O} 2}, K_{1} a_{, \mathrm{CO} 2}\right.$, and $\left.K_{1} a_{\text {, NH3 }}\right)$. Calibration was performed by comparing hourly measured data of $\mathrm{DO}$ and $\mathrm{pH}$ with simulation patterns using graphs over the 8 days of experiment in which the reactor was operated in continuous mode. Model data were compared to experimental data by the root mean square error (RMSE). Other tested components during calibration were the following: total inorganic carbon (TIC, sum of $\mathrm{S}_{\mathrm{HCO} 3}, \mathrm{~S}_{\mathrm{CO} 2}$, and $\left.\mathrm{S}_{\mathrm{CO} 3}\right)$, ammonium $\left(\mathrm{S}_{\mathrm{NH} 4}\right)$, nitrate $\left(\mathrm{S}_{\mathrm{NO} 3}\right)$, nitrite $\left(\mathrm{S}_{\mathrm{NO} 2}\right)$, phosphate $\left(\mathrm{S}_{\mathrm{PO} 4}\right)$, and $\mathrm{COD}$ removal efficiency and microorganism biomass $\left(C_{\mathrm{b}}\right.$, sum of $X_{\mathrm{ALG}}, X_{\mathrm{H}}, X_{\mathrm{AOB}}$, and $\left.X_{\mathrm{NOB}}\right)$ production.

Practical case study was conducted to evaluate the influence of pure $\mathrm{CO}_{2}$ injection on the performance of the system. Biomass production and removal efficiency obtained switch- 
Table 3 Initial concentrations of components in the culture medium of the pilot photobioreactor used for simulations. Data were recorded at 9:00 AM at the beginning of the continuous mode

\begin{tabular}{|c|c|c|c|}
\hline Components & Description & Concentrations & Units \\
\hline$S_{\mathrm{NH} 4}$ & Ammonium nitrogen & 1.38 & $\mathrm{gN}-\mathrm{NH}_{4} \mathrm{~m}^{-3}$ \\
\hline$S_{\mathrm{NH} 3}$ & Ammonia nitrogen & 0.01 & $\mathrm{gN}-\mathrm{NH}_{3} \mathrm{~m}^{-3}$ \\
\hline$S_{\mathrm{NO} 3}$ & Nitrate nitrogen & 0.3 & $\mathrm{gN}-\mathrm{NO}_{3} \mathrm{~m}^{-3}$ \\
\hline$S_{\mathrm{NO} 2}$ & Nitrite nitrogen & 0.04 & $\mathrm{gN}-\mathrm{NO}_{2} \mathrm{~m}^{-3}$ \\
\hline$S_{\mathrm{CO} 2}$ & Carbon dioxide & 6.67 & $\mathrm{gC}-\mathrm{CO}_{2} \mathrm{~m}^{-3}$ \\
\hline$S_{\mathrm{HCO} 3}$ & Bicarbonate & 86 & $\mathrm{gC}-\mathrm{HCO}_{3} \mathrm{~m}^{-3}$ \\
\hline$S_{\mathrm{CO} 3}$ & Carbonate & 0.18 & $\mathrm{gC}-\mathrm{CO}_{3} \mathrm{~m}^{-3}$ \\
\hline$S_{\mathrm{PO} 4}$ & Phosphate phosphorus & 1.8 & $\mathrm{gP}-\mathrm{PO}_{4} \mathrm{~m}^{-3}$ \\
\hline$S_{\mathrm{O} 2}$ & Dissolved oxygen & 6.49 & $\mathrm{gO}_{2} \mathrm{~m}^{-3}$ \\
\hline$S_{\mathrm{H}}$ & Hydrogen ions & $2.95 \mathrm{E}-8$ & $\mathrm{gH} \mathrm{m}^{-3}$ \\
\hline$S_{\mathrm{OH}}$ & Hydroxide ions & $3.99 \mathrm{E}-7$ & $\mathrm{gH}-\mathrm{OH} \mathrm{m}{ }^{-3}$ \\
\hline$S_{\mathrm{S}}$ & Readily biodegradable soluble organic matter & 7.5 & $\mathrm{gCOD} \mathrm{m^{-3 }}$ \\
\hline$S_{\text {I }}$ & Inert soluble organic matter & 42.5 & $\mathrm{gCOD} \mathrm{m}^{-3}$ \\
\hline$X_{\mathrm{ALG}}$ & Microalgae & 423 & $\mathrm{gTSS} \mathrm{m}^{-3}$ \\
\hline$X_{\mathrm{H}}$ & Heterotrophic bacteria & 92 & $\operatorname{gTSS~m}^{-3}$ \\
\hline$X_{\mathrm{AOB}}$ & Ammonium oxidizing bacteria & 0.037 & $\operatorname{gTSS~m}^{-3}$ \\
\hline$X_{\mathrm{NOB}}$ & Nitrite oxidizing bacteria & 0.032 & $\operatorname{gTSS~m}^{-3}$ \\
\hline$X_{\mathrm{S}}$ & Slowly biodegradable particulate organic matter & 20 & $\operatorname{gTSS~m}^{-3}$ \\
\hline$X_{\mathrm{I}}$ & Inert particulate organic matter & 145 & $\operatorname{gTSS~m}^{-3}$ \\
\hline
\end{tabular}

$X_{\mathrm{ALG}}, X_{\mathrm{S}}, X_{\mathrm{H}}, X_{\mathrm{I}}, X_{\mathrm{AOB}}$, and $X_{\mathrm{NOB}}$ concentrations were estimated from TSS concentration (see text). $S_{\mathrm{S}}$ and $S_{\mathrm{I}}$ were estimated from previous simulation tests off $\mathrm{CO}_{2}$ injection were compared with simulation results from model calibration. Moreover, the model was applied using two different influent wastewater compositions from centrate and manure (Table 2). In these studies, starting from the same operation mode and environmental conditions (i.e., temperature and irradiance) used during the model calibration, the concentration of each components of the model was simulated. Again, biomass production, the relative proportion of microalgae and bacteria COD removal efficiency, and nutrient uptake were evaluated.

\section{Results}

To perform the calibration of BIO_ALGAE 2 model, hourly experimental data of $\mathrm{pH}$ and $\mathrm{DO}$ from the stirred tank reactors were used. Although BIO_ALGAE model was calibrated and validated in different systems (Solimeno et al. 2015, 2017a, 2017c; Solimeno and García 2019), these previous works have proved that the parameters related to the transfer of gases to the atmosphere $\left(K_{1} a_{1}, \mathrm{O} 2, K_{1} a_{1, \mathrm{CO} 2}\right.$, and $\left.K_{1} a_{1}, \mathrm{NH} 3\right)$ were very sensitive and likely to be calibrated in each application of the model. The mass transfer coefficient $K_{1} a_{1}, j$ (day $^{-1}$ ) of $j$ th gas species depends on the physical properties of the system (i.e., nature of the gas, culture medium, extension of the surface interface and temperature) and on the hydrodynamic conditions in the bioreactors. It is very challenging to find a correlation between mass transfer coefficients and the characteristics of reactors. Note that
$K_{1} a_{1}, \mathrm{O} 2, K_{1} a_{1}, \mathrm{CO}_{2}$, and $K_{1} a_{1}, \mathrm{NH} 3$ were calibrated in order to fit the model with experimental data. The results shown in Fig. 1a, b were obtained running the model with the values of the three calibrated parameters presented in Table 4 .

Simulations were able to follow the wave-like pattern of DO concentrations and $\mathrm{pH}$ values over the 8 days of experiment in which the reactor was operated in continuous mode (Fig. 1a, b). As can be seen, $\mathrm{pH}$ and $\mathrm{DO}$ values have a daily wavelike pattern due mostly to microalgae photosynthetic activity. This trend is in agreement with previous simulation results obtained in our previous works (Solimeno et al. 2017a; Solimeno and García 2019) and also with previous experimental studies (García et al. 2006). Low experimental data of $\mathrm{pH}$ were due to cleaning operation of probes.

In Fig. 1b, injection of pure $\mathrm{CO}_{2}$ during daytime allowed to control $\mathrm{pH}$ below 8.0. Figure $1 \mathrm{c}$ shows the flow rate of $\mathrm{CO}_{2}$ injection in both simulated and experimental data. During night, $\mathrm{CO}_{2}$ injection was 0 and reach up to $6.0 \mathrm{E}$ $-03\left(\mathrm{~mol} \mathrm{CO}_{2} \mathrm{~h}^{-1}\right)$ at midday. Elevated $\mathrm{pH}(>8.3)$ that could occur in microalgae-bacteria systems can negatively affect aerobic bacteria and shift the equilibrium of carbon species towards to carbonate concentrations, inhibiting microalgae growth (García et al. 2000). In fact, inorganic biogenic carbon includes bicarbonate $\left(\mathrm{HCO}_{3}{ }^{-}\right)$and carbon dioxide, whereas carbonate $\left(\mathrm{CO}_{3}{ }^{2-}\right)$ is not biogenic and therefore has not to be considered as substrate for microalgae (Solimeno et al. 2017a). 
Moreover, BIO ALGAE 2 model was able to simulate biomass concentration $\left(C_{\mathrm{b}}\right)$ and the relative proportion of $X_{\mathrm{ALG}}$ and $X_{\mathrm{H}}$ (Fig. 2a, b). Simulation results have demonstrated that much of the biomass corresponds to $X_{\mathrm{ALG}}(65 \%$ in average of $C_{\mathrm{b}}$ ) and $X_{\mathrm{H}}(15 \%)$ (Fig. 2a). Nitrifier biomass $\left(X_{\mathrm{AOB}}+X_{\mathrm{NOB}}\right)$ is comparatively very low $(0.55 \%)$ (Fig. $\left.2 \mathrm{~b}\right)$. The remaining solids are attributable to $X_{\mathrm{S}}(9 \%)$ and $X_{\mathrm{I}}$ (10.4\%). These proportions have been also obtained in previous simulation studies (Solimeno et al. 2017a; Solimeno and García 2019). Moreover, Park and Craggs (2010) showed that the proportion of microalgae in the microalgae/bacteria biomass of a high-rate algal pond (HRAP) operating at 4-day HRT with $\mathrm{CO}_{2}$ addition was around $80.5 \%$ using secondary inlet wastewater. Biomass production calculated from simulation result $\left(C_{\mathrm{b}}=155 \mathrm{gTSS} \mathrm{m}{ }^{-3}\right.$ day $\left.^{-1}\right)$ matches pretty well the value of biomass obtained experimentally $\left(C_{\mathrm{b}}=\right.$ $151 \mathrm{gTSS} \mathrm{m}^{-3}$ day $^{-1}$ ).

\section{Discussion}

In this work, the parameters related to the transfer of gases to the atmosphere present in the BIO_ALGAE model were calibrated in a pilot photobioreactor. Simulation results shown in Figs. 1 and 2 were performed calibrating only the three parameters related to the transfer of gases to the atmosphere $\left(K_{1} a_{1}, \mathrm{O} 2, K_{1} a_{1}, \mathrm{CO} 2\right.$, and $\left.K_{1} a_{1, \mathrm{NH} 3}\right)$ with respect to the 108 parameters included in the BIO_ALGAE. Some of these
Fig. 1 Experimental (red triangles) and simulated (blue line). a DO and $\mathbf{b} \mathrm{pH}$ values and $\mathbf{c}$ $\mathrm{CO}_{2}$ molar flow injection over the 8 days of experiment in continuous mode. Data used for calibration

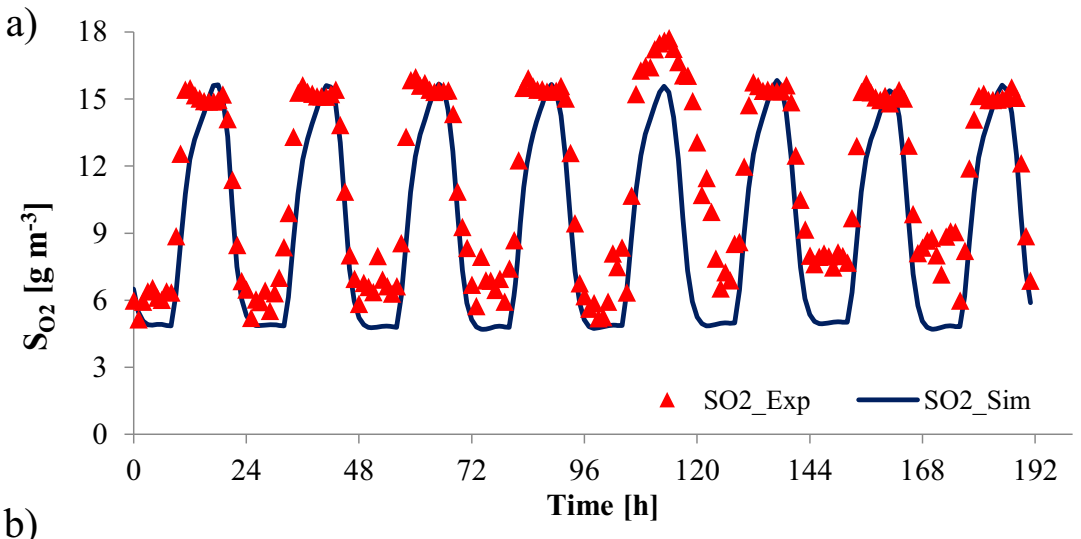

b)

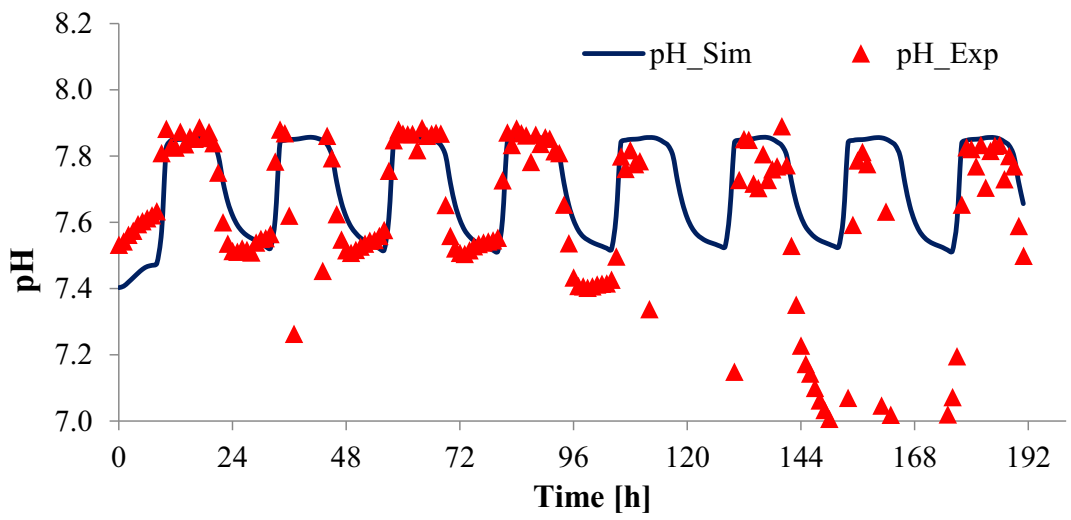

c)

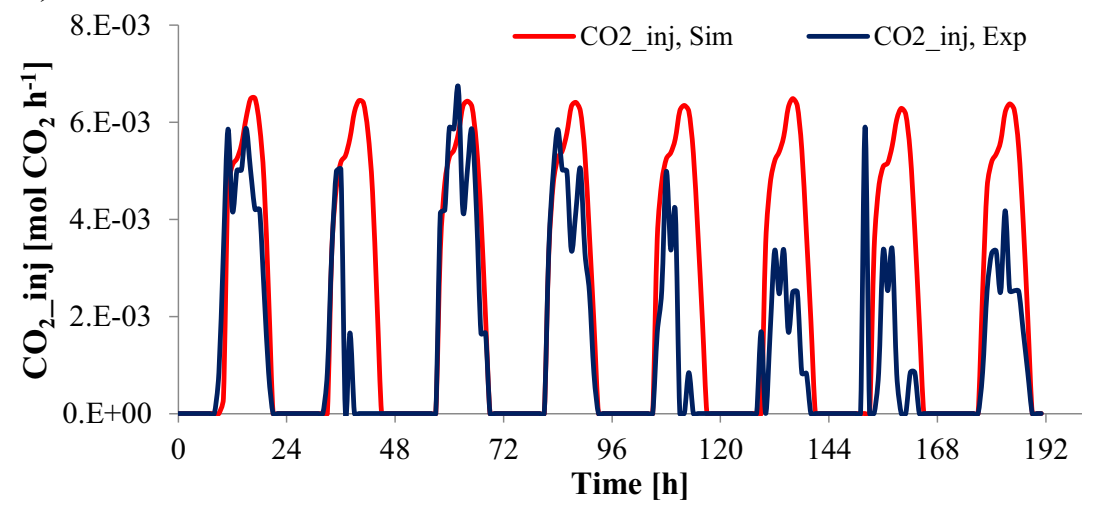


Table 4 Values of calibrated parameters

\begin{tabular}{lll}
\hline Parameter & Description & Value \\
\hline$K_{1} a_{, \mathrm{O} 2}$ & Mass transfer coefficient for oxygen & 16 day $^{-1}$ \\
$K_{1} a_{, \mathrm{CO} 2}$ & Mass transfer coefficient for dioxide carbon & $5 \mathrm{day}^{-1}$ \\
$K_{1} a_{\mathrm{NH} 3}$ & Mass transfer coefficient for ammonia & 5 day $^{-1}$ \\
\hline
\end{tabular}

parameters (i.e., maximum microalgae and heterotrophic growth rate) were calibrated and validated in our previous work (Solimeno et al. 2017a; Solimeno and García 2019). In order to validate the values of $K_{1} a_{1}, \mathrm{O} 2, K_{1} a_{1}, \mathrm{CO} 2$, and $K_{1} a_{1}$, NH3 , calibrated in this work, experimental studies were conducted to evaluate the mass transfer coefficient to the atmosphere for $\mathrm{DO}$ and $\mathrm{CO}_{2}$ as function of different rotating magnetic stirrer $(0,350,400$, and $450 \mathrm{rpm})$. The correct measurement and/or prediction of the $K_{1} a_{1}, i$ is a crucial step in the design, operation, and scale-up of bioreactors. Starting from the same reactor used for model calibration and saturating the medium of oxygen and pure $\mathrm{CO}_{2}$ in turn, $\mathrm{DO}$ and $\mathrm{CO}_{2}$ concentrations were calculated operating in batch mode. Consumption and/or production of oxygen and $\mathrm{CO}_{2}$ by microorganism's activity could interfere with results; for this reason, freshwater was used as medium. Figure 3 shows the effect of liquid agitation on the overall mass transfer coefficient $\left(K_{1} a_{1}, \mathrm{O} 2\right.$ and $\left.K_{1} a_{1}, \mathrm{CO} 2\right)$. It is found that an increase of rotation speed involves in an exponential increase of $K_{1} \mathrm{a}_{1}, \mathrm{O} 2$ and $K_{1} a_{1, \mathrm{CO} 2}$ value. The increase of $K_{1} a_{1, \mathrm{CO} 2}$ as function of rotation speed was not relevant as for $K_{1} a_{1}, \mathrm{O} 2$.

As is seen in Fig. 3, the values of $K_{1} a_{1}, \mathrm{O} 2$ and $K_{1} a_{1}, \mathrm{CO} 2$ obtained during the calibration of the model (16 and 5 day $^{-1}$, respectively) fit quite well with experimental results (13.4 and 5.06 day $^{-1}$, respectively) corresponding at rotation speed inside the reactor of $400 \mathrm{rpm}$. The root mean square error of the simulation was low in relation to measured values $\left(\mathrm{RMSE}_{\mathrm{O} 2}=1.8\right.$ and $\left.\mathrm{RMSE}_{\mathrm{pH}}=0.25 \mathrm{~g} \mathrm{O}_{2} \mathrm{~m}^{-3}\right)$. Values of RMSE for the two parameters considered for calibration were obtained comparing model simulations with experimental data $(n=191)$ for dissolved oxygen and $\mathrm{pH}$. Transfer coefficient to the atmosphere for ammonia $\left(\mathrm{NH}_{3}\right)$ was assumed equal to the $K_{1} a_{1}, \mathrm{CO} 2$ due to the same value of diffusion coefficient (Frank et al. 1996).

The implementation of the cardinal $\mathrm{pH}$ and temperature sub-models allowed to consider the negative effects on photosynthetic metabolism and bacteria growth when $\mathrm{pH}$ and temperature values move away of the optimal value. Figure $4 \mathrm{a}$ shows the influence of $\mathrm{pH}$ values on growth rate of microalgae, heterotrophic, and nitrifier bacteria. As can be
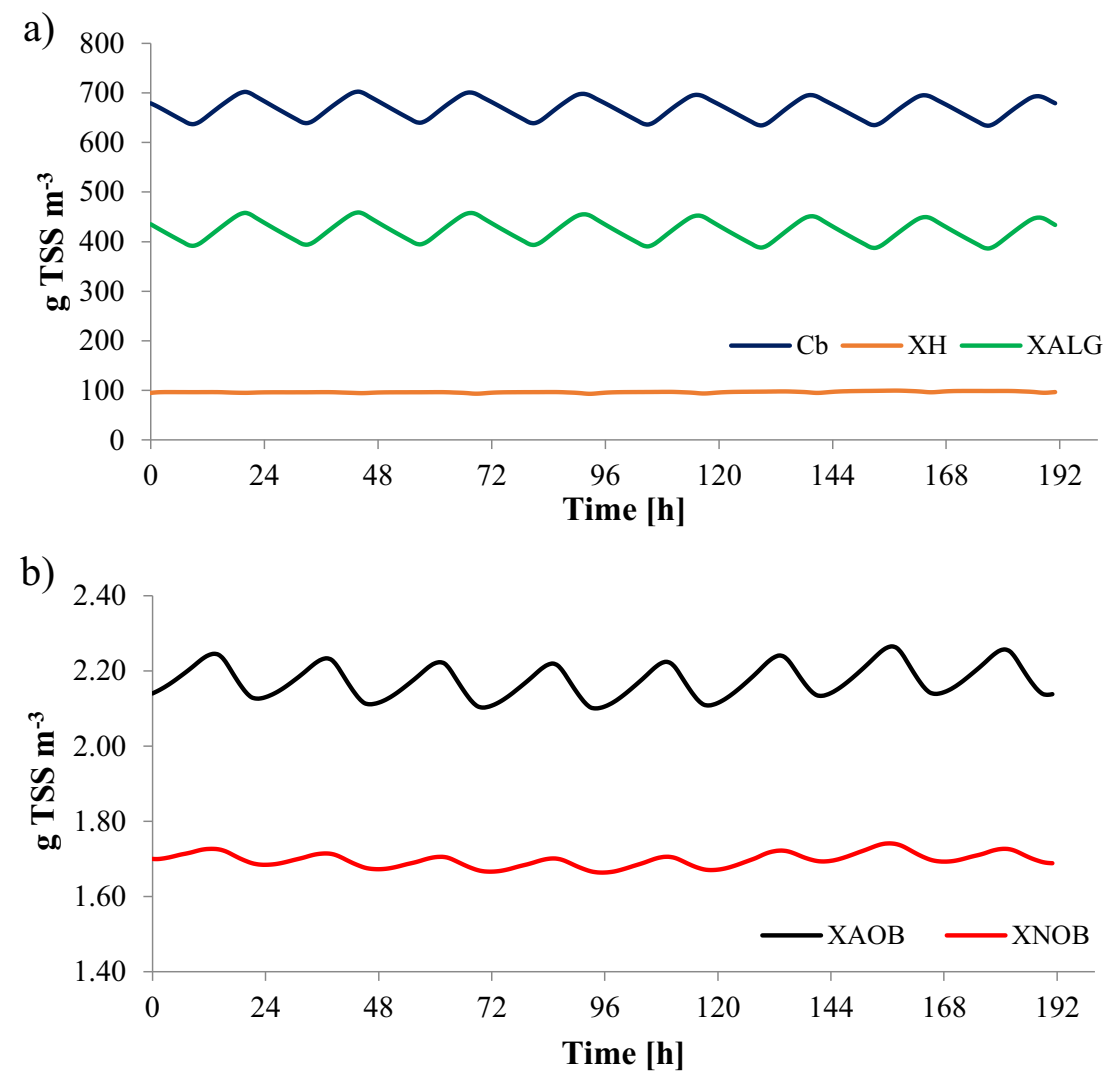

Fig. 2 Simulated a $C_{\mathrm{b}}$ (blue line), microalgae (green line), and heterotrophic bacteria (orange line); b nitrifier bacteria (black and red lines); influent (blue line) and effluent simulated concentration (green line) e TIC, d $\mathrm{S}_{\mathrm{NH} 4}$, e $\mathrm{S}_{\mathrm{NO} 3}$ and $\mathrm{S}_{\mathrm{NO} 2}$, f $\mathrm{S}_{\mathrm{PO} 4}$, and $\mathbf{g} \mathrm{COD}$ over the 8 days of experiment in continuous mode 

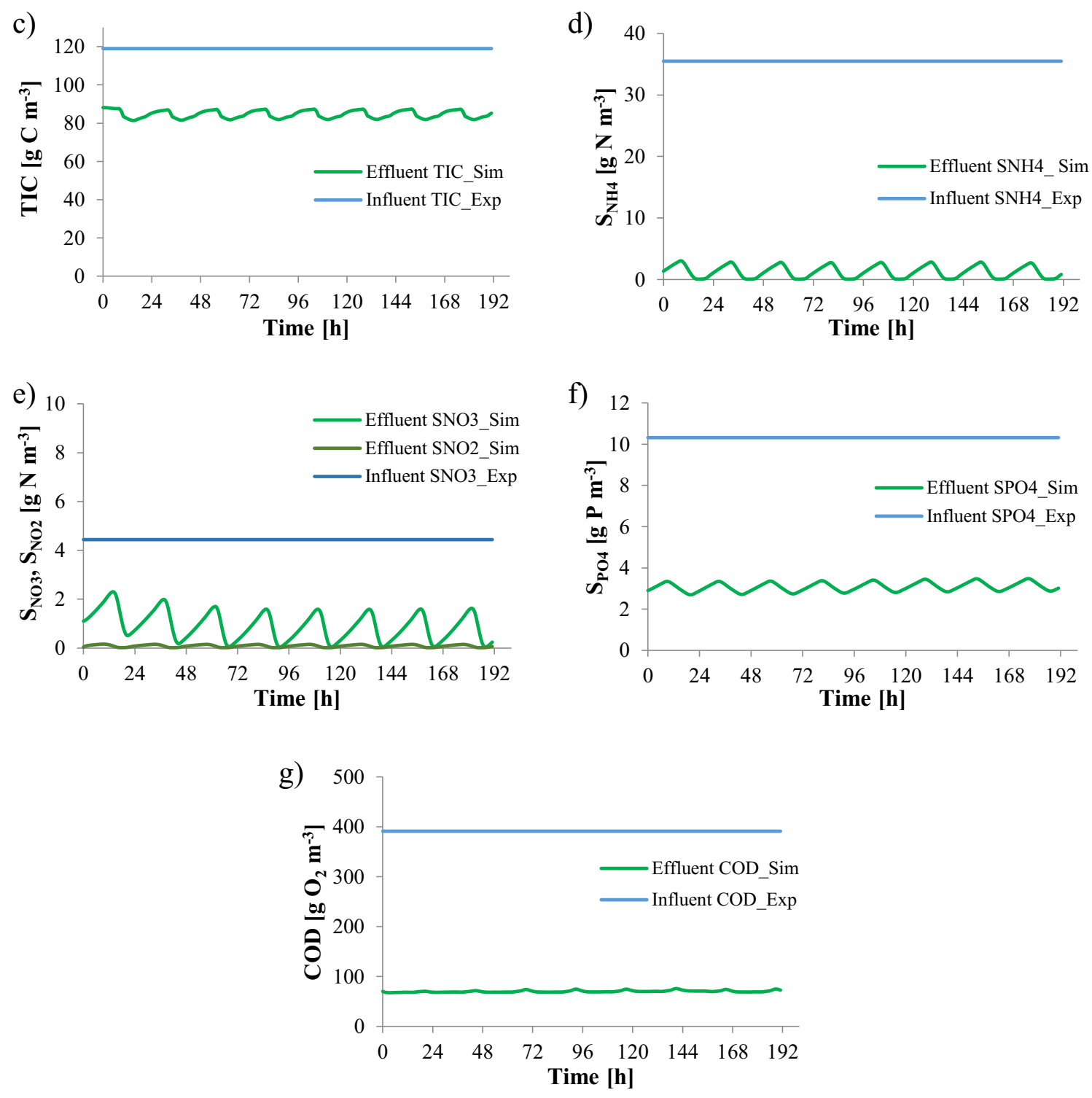

Fig. 2 (continued)

seen, microalgae growth rate was slowly reduced by $5 \%$ during photosynthetic hour activity due to the $\mathrm{CO}_{2}$ injection that control $\mathrm{pH}(<8.0)$. The implementation of $\mathrm{CO}_{2}$ injection allows to reproduce the effect of a control system of carbon dioxide injection as function of an establish $\mathrm{pH}$ value. Moreover, by model simulation, it is possible to quantify the amount of $\mathrm{CO}_{2}$ that is needed in the microalgae metabolism.

Figure $4 \mathrm{~b}$ reproduces the values of cardinal temperature factor for microalgae and nitrifier bacteria and the thermic factor for heterotrophic bacteria, which follow the Arrhenius type model. Temperature values recorded during the experiment did not influence negatively the growth rate of each microorganism species.

Temperature is one of the main factors that strongly influence the maximum growth rate for microalgae (Singh and Singh 2015). Several studies have reported that the optimal growth rate for microalgae varies between species to species as function of temperature (Talbot et al. 1991; Saunders and Giskle 1997; Bouterfas et al. 2002; Pereira et al. 2006). Accordingly to Park et al. (2011), temperatures between 28 and $35^{\circ} \mathrm{C}$ are favorable for microalgae growth. With respect to the thermic photosynthetic factor $\left(f_{\mathrm{T}, \mathrm{FS}}\right)$ reported on the previous version of BIO_ALGAE model (Solimeno et al. 2017a), the cardinal temperature sub-model allows to consider the optimal temperature range for each species of microalgae. In our case, through the cardinal model, it was possible to consider the specific minimum, maximum, and optimal temperature values for Scenedesmus almeriensis (Table S6b), which can tolerate temperature up to $45{ }^{\circ} \mathrm{C}$ (Sánchez et al. 2008; Costache and Fernández 2013).

BIO_ALGAE model has allowed to simulate microalgae and bacteria proportion and to estimate daily biomass 
Fig. 3 Influence of rotating magnetic stirrer on overall mass transfer coefficient for $\mathrm{DO}$ and $\mathrm{CO}_{2}$

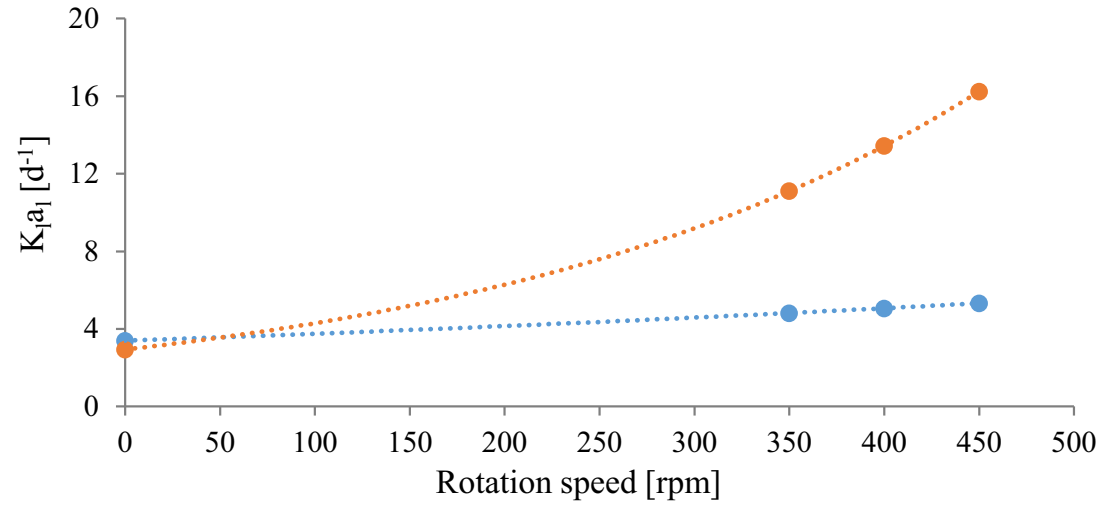

production. Furthermore, the model was able to reproduce TIC, $S_{\mathrm{NH} 4}, S_{\mathrm{NO} 3}, S_{\mathrm{NO} 2}, S_{\mathrm{PO} 4}$, and COD concentrations (Fig. $2 \mathrm{c}-\mathrm{g})$. Simulated curves present a clear wavelike pattern mostly related to photosynthesis, with lower values during daytime. Microalgae grow during daytime using bicarbonate such as carbon source, ammonia, and nitrate such as nitrogen source and phosphate. Figure $2 \mathrm{c}-\mathrm{f}$ show the comparison of simulated outflow concentration of nutrients and organic matter (Fig. 2g) and their respective inflow concentrations. In accordance with the removal efficiency values described in Table 5, the results carried out by BIO ALGAE 2 model fit quite well with the experimental results. The model considers the removal of both microalgae and bacteria separately, although the result of global removal is that provided by the model.

\section{Case study: biomass production and wastewater treatment performance without $\mathrm{CO}_{2}$ injection}

In this case study, the reactor was operated in continuous mode likewise of the model calibration but switch-off $\mathrm{CO}_{2}$ injection. The effects of not supply $\mathrm{CO}_{2}$ on biomass production and relative proportion of microalgae and bacteria were compared with previous results obtained supplying pure $\mathrm{CO}_{2}$ to control $\mathrm{pH}$ below 8.0. As is observed in Fig. $5 \mathrm{a}$, simulation indicated that $C_{\mathrm{b}}$ slightly decreases from

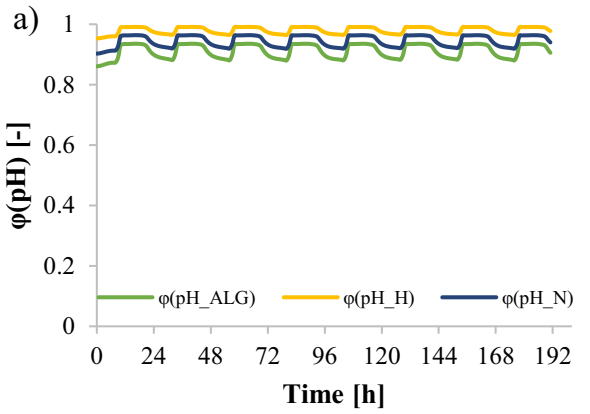

Fig. 4 a Changes of the values of the cardinal function $\varphi(\mathrm{pH})$ for microalgae (green line), heterotrophic (blue line), and nitrifier bacteria (yellow line) over the over the 8 days of experiment in continuous mode. b Changes of the values of the cardinal function $\varphi(T)$ for
$155 \mathrm{gTSS} \mathrm{m}^{-3}$ day $^{-1}$ to $122 \mathrm{gTSS} \mathrm{m}^{-3}$ day $^{-1}$ without $\mathrm{CO}_{2}$ injection, but the relative proportions of particulate components with respect to $C_{\mathrm{b}}$ changed. $X_{\mathrm{ALG}}$ decreased by $38 \%$ and $X_{\mathrm{H}}$ increased by $35 \%$ with respect to model calibration. Low amount of nitrifier biomass (1\%) compared to heterotrophic bacteria comparatively is in agreement with previous simulation studies (Sams and García 2013; Krasnits et al. 2009; Silyn-Roberts and Lewis 2001). The decrease of $X_{\mathrm{ALG}}$ has caused a less competition on nutrients availability (nitrogen and phosphorous) determining the proliferation of $X_{\mathrm{H}}$.

From simulation, microalgae result is not carbon limited due to the increase of $\mathrm{pH}$ up to 11.0 at midday. Figure $5 \mathrm{~b}$ shows the influence of $\mathrm{pH}$ values on growth rate of $X_{\mathrm{ALG}}$, $X_{\mathrm{H}}, X_{\mathrm{AOB}}$, and $X_{\mathrm{NOB}}$. In comparison with $\mathrm{pH}$ cardinal values showed in Fig. 4a, $X_{\mathrm{ALG}}$ growth rate was reduced from 5 to $10 \%$ during photosynthetic activity due to the absence of $\mathrm{CO}_{2}$ injection that control $\mathrm{pH}$. Although the growth rate of $X_{\mathrm{H}}$ was strongly reduced by $30 \%$ during the day and $80 \%$ at night, the effect of high $\mathrm{pH}$ value was negligible in terms of COD removal efficiency (Fig. 5c). This result is in accordance with previous study by Posadas et al. (2014). $\mathrm{NH}_{4}{ }^{+}-\mathrm{N}$ stripping has been proposed as the main process contributing to nitrogen removal in HRAPs (Shelef et al. 1982; El Halouani et al. 1993). Nevertheless, model simulations have indicated that microalgae uptake is the main mechanism for nitrogen

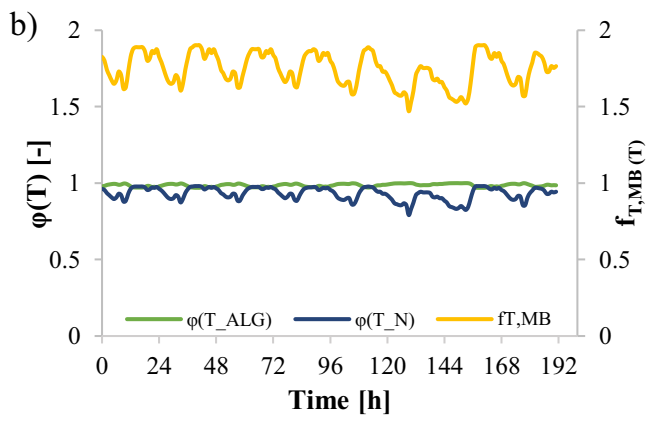

microalgae (green line) and nitrifier bacteria (yellow line), and thermal factor $\left(f_{\mathrm{T} \_\mathrm{MB}}\right)$ for heterotrophic (blue line) over the over the 8 days of experiment in continuous mode 
Table 5 Comparison between removal efficiency of the system measured experimentally and obtained by model simulation

\begin{tabular}{lll}
\hline & \% Removal efficiency experimental results & \% Removal efficiency model results \\
\hline TIC & 27.2 & 27.7 \\
N_NH4 & 96.1 & 92.4 \\
N_NO3 & 75.0 & 73.6 \\
P_PO4 & 94.1 & 67.60 \\
COD & 90.8 & 91.1 \\
\hline
\end{tabular}

removal. Although $\mathrm{NH}_{4}{ }^{+}-\mathrm{N}$ stripping is promoted at high $\mathrm{pH}$, model results have estimated that microalgae activity is responsible for $60 \%$ of nitrogen removal and only $30 \%$ is due to stripping, in agreement with previous works (Avoz and Goldmann 1982, García et al. 2000). Regarding phosphorous removal, Fig. 5c shows that only $20 \%$ of phosphorous is assimilated by microalgae in absence of $\mathrm{CO}_{2}$ injection. The remaining phosphorous concentrations is precipitate from the medium; in fact, $\mathrm{pH}$ values between 9 and 11 induced the precipitation of phosphorus in the form of calcium phosphate (Laliberte et al. 1997). Phosphorous precipitation at high $\mathrm{pH}$ values was not included in the model.
Fig. 5 a Comparison of biomass production $\left(C_{\mathrm{b}}\right)$ and relative production of $X_{\mathrm{ALG}}, X_{\mathrm{H}}, X_{\mathrm{AOB}}$, and $X_{\mathrm{NOB}}$ as function of $\mathrm{CO}_{2}$ injection. $\mathbf{b}$ Changes of the values of the cardinal function $\varphi(\mathrm{pH})$ for $X_{\mathrm{ALG}}$ (green line), $X_{\mathrm{H}}$ (blue line), and nitrifier bacteria $\left(X_{\mathrm{AOB}}+\right.$ $X_{\mathrm{NOB}}$ (yellow line) over the over the 8 days of experiment in continuous mode without $\mathrm{CO}_{2}$ injection. $\mathbf{c}$ Comparison of wastewater treatment performance using $\mathrm{CO}_{2}$ injection and without $\mathrm{CO}_{2}$ injection a)
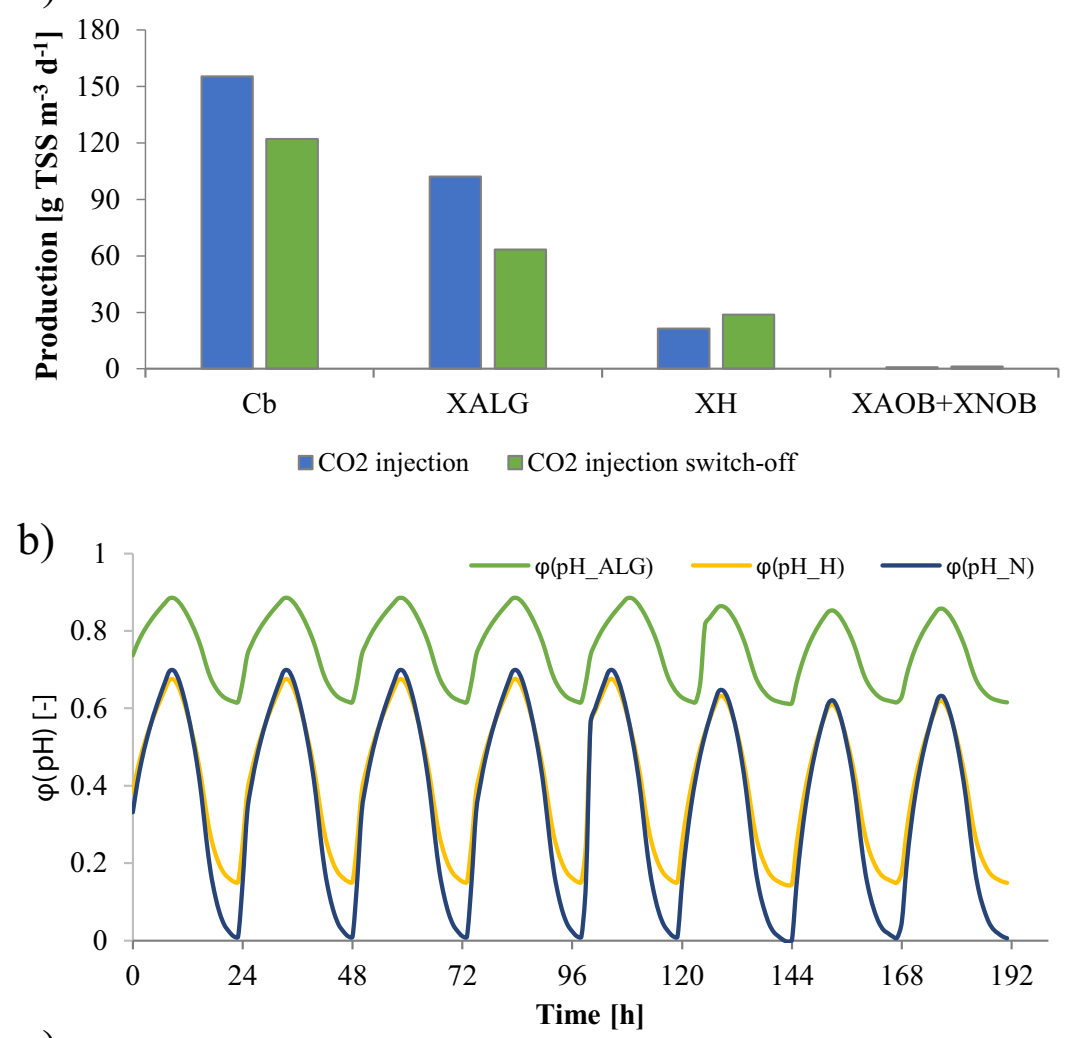

c)

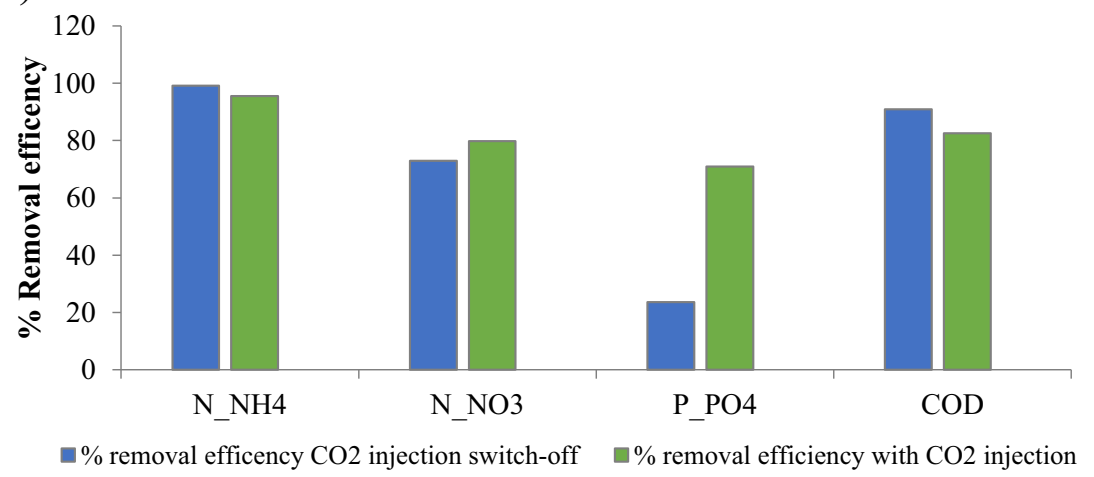


a)

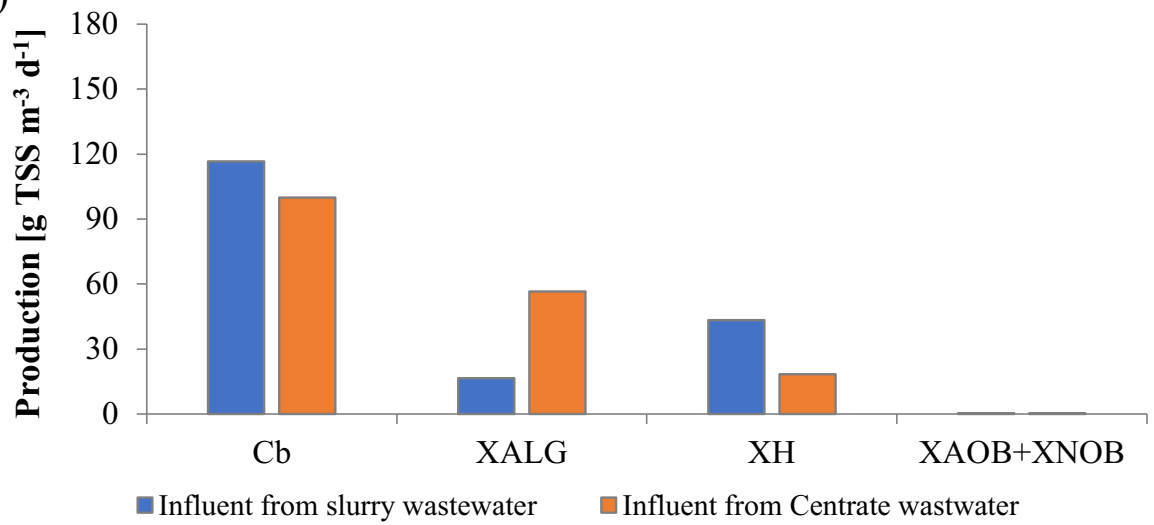

b)

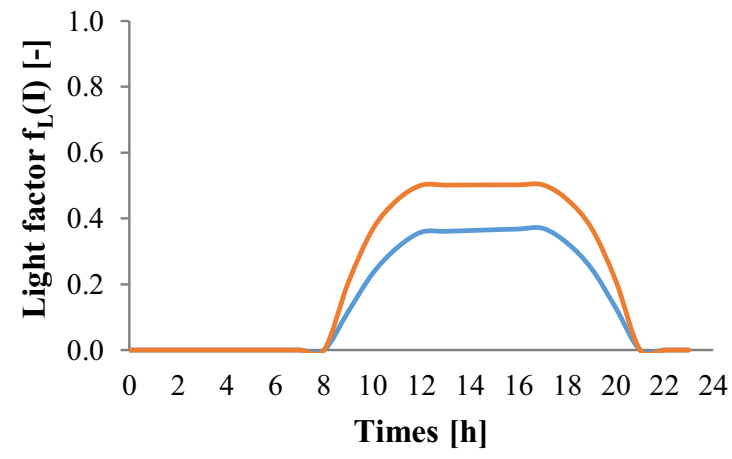

Fig. 6 a Comparison of biomass production $\left(C_{\mathrm{b}}\right)$ and relative production of $X_{\mathrm{ALG}}, X_{\mathrm{H}}, X_{\mathrm{AOB}}$, and $X_{\mathrm{NOB}}$ as function of type of influent wastewater (manure and centrate). $\mathbf{b}$ Comparison of the values of light factor $\left(f_{\mathrm{L}}(I)\right)$ between influent wastewater from manure (blue line) and centrate (orange

\section{Case study: biomass production and wastewater treatment performance with different influent wastewater composition}

In this case study, the photobioreactor was alimented using two different influent wastewater from centrate and manure (Table 2). In Fig. 6a, the relative proportion of each particulate components is compared. As it can be seen, microalgae/ bacteria proportions is completely different as function of influent wastewater composition. Using manure wastewater, $X_{\mathrm{H}}$ production predominant with respect to $X_{\mathrm{ALG}}$, while using centrate wastewater the relative proportion is exactly the opposite. Moreover, model simulations have indicated that $C_{\mathrm{b}}$ production $\left(\sim 100 \mathrm{gTSS} \mathrm{m}^{-3}\right.$ day $^{-1}$ for both cases) resulted lower than $C_{\mathrm{b}}$ production obtained using primary influent wastewater $\left(155 \mathrm{gTSS} \mathrm{m}^{-3}\right.$ day $\left.^{-1}\right)$.

Low biomass production could be due to inorganic carbon limitation for the growth of microalgae. In general, microalgae growing in wastewater systems such as high rate algal ponds or photobioreactors, in which no external $\mathrm{CO}_{2}$ is supplied, are usually carbon limited (Park et al. 2011; García et al. 2006; Oswald 1988). Looking more closely at model outputs was possible to investigate which was the factor that more affects c)

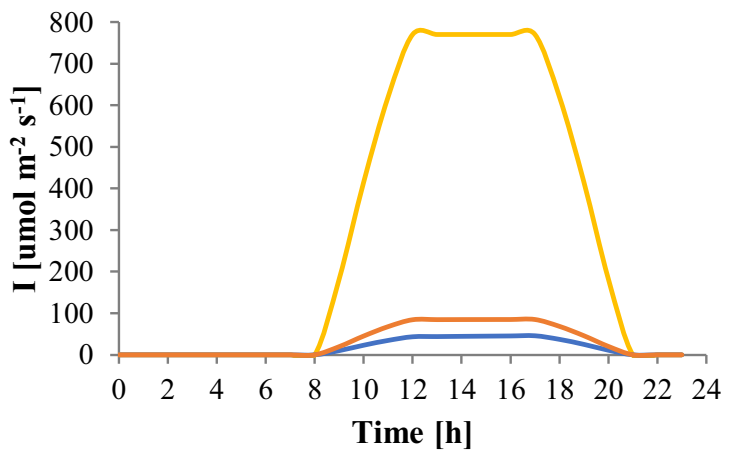

line). c Incident light intensity $\left(I_{0}\right)$ (yellow line) and average light intensity $\left(I_{\text {av }}\right)$ in the pond for influent wastewater from manure (blue line) and centrate (orange line)

microalgae concentrations. Both system results are not carbon limited, and $\mathrm{CO}_{2}$ injection to control $\mathrm{pH}$ was not necessary. Low photosynthetic activity by microalgae during daytime has allowed to maintain $\mathrm{pH}$ value below 8.2. In particular, a constant value of $\mathrm{pH}$ around 7.5 was recorded for the pilot photobioreactor alimented with wastewater influent from manure, while using centrate as influent wastewater $\mathrm{pH}$ value ranged between 7.7 at night and 8.2 during the day.

Figure $6 \mathrm{~b}$ shows the trend of the light factor $f_{\mathrm{L}}(I)$ (processes 1a, $1 \mathrm{~b}$ in Table S1 in SD) (Solimeno et al. 2015) over the $24 \mathrm{~h}$ for both manure and centrate influent wastewater. As can be seen, microalgae were strongly influenced by the light factor $f_{\mathrm{L}}(I)$, which reduced growth from 65 to $50 \%$, respectively for manure and centrate wastewater during the photosynthesis's hours. Light factor includes photoinhibition, photolimitation, and light attenuation and is considered to be the main limiting factor in microalgae systems (Larsdotter 2006). Incident light intensity $\left(I_{0}\right)$ and average light intensity $\left(I_{\text {av }}\right)$ are compared in Fig. 6c (Solimeno et al. 2017a). $I_{\mathrm{av}}$ have a direct effect on the values of the light factor.

Light attenuation results the main limiting factor for both cases. Elevated particulate components concentrations $\left(X_{\mathrm{H}}\right.$, $X_{\mathrm{S}}$, and $X_{\mathrm{I}}$ ) present in theses wastewaters reduced the light 
Table 6 Comparison between removal efficiency of the system using manure and centrate as influent wastewater
$\%$ Removal efficiency using manure as influent

$\%$ Removal efficiency using centrate as influent

\begin{tabular}{lll}
\hline N_NH4 & 25.2 & 48.8 \\
N_NO3 & 47.7 & 5.0 \\
P_PO4 & 52.5 & 13.0 \\
COD & 75.0 & 50.0 \\
\hline
\end{tabular}

availability in the culture medium. Average light intensity $\left(I_{\mathrm{av}}\right.$ $\left[\mu \mathrm{mol} \mathrm{m} \mathrm{m}^{-2} \mathrm{~s}^{-1}\right]$ ) was described using Lambert-Beer's law and is attenuated by the presence of particulate components $\left(X_{\mathrm{C}}=\right.$ $\left.X_{\mathrm{ALG}}+X_{\mathrm{H}}+X_{\mathrm{I}}+X_{\mathrm{S}}+X_{\mathrm{AOB}}+X_{\mathrm{NOB}}\left[\mathrm{g} \mathrm{TSS} \mathrm{m}^{-3}\right]\right)$ and the depth $(\mathrm{d}[\mathrm{m}])$ of the reactors (Eq. 5).

$I_{\mathrm{av}}=\frac{I_{0} \cdot\left(1-\exp \left(K_{i} \cdot X_{\mathrm{C}} \cdot d\right)\right.}{K_{i} \cdot X_{\mathrm{C}} \cdot d}$

where $I_{0}\left(\mu \mathrm{mol} \mathrm{m} \mathrm{m}^{-2} \mathrm{~s}^{-1}\right)$ is the incident light intensity and $K_{i}$ is the extinction coefficient for particulate biomass $\left(0.07 \mathrm{~m}^{2} \mathrm{~g}^{-1}\right)$ (Molina Grima et al. 1994).

In a dense culture medium such as from manure wastewater, the growth rate of microalgae is reduced; conversely, bacteria growth rate is not limited because it does not depend on light availability, but on quality of influent wastewater. For this reason, the relative proportion on microalgae/bacteria is shifted towards heterotrophic bacteria. Regarding a culture medium from centrate wastewater, although microalgae are limited by light availability, microalgae/bacteria proportion (70\%) is in accordance with experimental results (Park and Craggs Park et al. 2011) and simulation results (Solimeno et al. 2017a) from a pilot high-rate algal pond (HRAP) treating municipal wastewater. As shown in Table 1b, influent $\mathrm{COD}_{\text {TOT }}$ of centrate wastewater is $371 \mathrm{gO}_{2} \mathrm{~m}^{-3}$ with respect to $840 \mathrm{gO}_{2} \mathrm{~m}^{-3}$ for manure wastewater. Therefore, centrate wastewater could be comparable with influent characteristic wastewater using during the experiment conducted by Park and Craggs (Park et al. 2011) and Solimeno et al. (2017a), $\mathrm{COD}_{\mathrm{TOT}}=180 \mathrm{gO}_{2} \mathrm{~m}^{-3}$ and $\mathrm{COD}_{\mathrm{TOT}}=232 \mathrm{gO}_{2} \mathrm{~m}^{-3}$, respectively. Furthermore, wastewater treatment performance of system was evaluated. Table 6 indicates that for both types of influent wastewater, the removal efficiency was very low.

The next step in order to make microalgae-based wastewater treatment sustainable systems would be to find the optimal condition in order to maximize biomass production and COD and nutrient removal efficiency using different type of influent wastewater.

\section{Conclusion}

In this work, the parameters related to the transfer of gases to the atmosphere present in the BIO_ALGAE model were calibrated in a pilot photobioreactor. Results of the calibration have indicated that the model quite accurately matched the $\mathrm{pH}$ and DO trend. Moreover, the model has allowed to simulate the relative proportion of microalgae and bacteria and to estimate daily biomass production. BIO_ALGAE model has demonstrated by means of practical study cases to be a useful tool to understand microalgae and bacteria interactions in wastewater treatment and in particular to study the effect of $\mathrm{CO}_{2}$ injection on wastewater treatment performance and biomass production. The model was applied to investigate the performance of microalgae-bacteria wastewater treatment using different influent wastewaters from primary or secondary municipal effluent. The next step in order to make microalgal-bacterial wastewater treatment sustainable systems would be to find the optimal condition in order to maximize biomass production and COD and nutrient removal efficiency using different types of influent wastewater. Further improvements should be focused on oxygen and $\mathrm{NH}_{3}$ desorption phenomena not only through the surface of the reactor but also in aerated zones (i.e., paddlewheel, sump) existing in large-scale reactors.

Acknowledgments The authors thank the GEMMA group of Technical University of Catalonia (UPC) for providing COMSOL Multiphysics license.

Funding This work was supported by Ministry of Economy and Competitiveness (EDARSOL, CTQ2014-57293-C3-1-R) and by European Union's Horizon 2020 Research and Innovation program through the project SABANA (Grant Agreement No. 727874).

\section{Compliance with ethical standards}

Conflict of interest The authors declare that they have no conflict of interest.

Ethical approval This article does not contain any studies with human participants or animals performed by any of the authors.

\section{References}

Acien F, Fernández Sevilla JM, Molina Grima E (2013) Photobioreactors for the production of microalgae. Environ Sci Biotechnol 12(2): $131-151$

Acien F, Gómez Serrano C, Morales Amaral MM, Fernández Sevilla JM, Molina Grima E (2016) Wastewater treatment using microalgae: how realistic a contribution might it be to significant urban wastewater treatment? Appl Microbiol Biotechnol 100(21):9013-9022 
Avoz Y, Goldman JC 1982. Free ammonia inhibition of algal photosynthesis in intensive culture. Appl. Environ. Microbiol. 43, 735-739.

Bernard O, Rémond B (2012) Validation of a simple model accounting for light and temperature effect on microalgal growth. Bioresour Technol 123:520-527

Bisutti I, Hilke I, Raessler M (2004) Determination of total organic carbon - an overview of current methods. Trends Anal Chem 23:10-11

Bouterfas R, Belkoura M, Dauta A (2002) Light and temperature effects on the growth rate of three freshwater algae isolated from a eutrophic lake. Hydrobiologia 489(1-3):207-217

Brennan L, Owende P (2010) Biofuels from microalgae - a review of technologies for production, processing, and extractions of biofuels and co-products. Renew Sust Energ Rev 14(2):557-577

Buhr HO, Miller SB (1983) A dynamic model of the high-rate algal bacterial wastewater treatment pond. Water Res 17:29-37

Chisti Y (2007) Biodiesel from microalgae. Biotechnol Adv 25(3):294 306

Costache TA, Fernández FGA (2013) Comprehensive model of microalgae photosynthesis rate as a function of culture conditions in photobioreactors. Appl Microbiol Biotechnol 97(17):7627-7637

Craggs R, Lundquist TJ, Benemann JR (2013) Wastewater treatment and algal biofuel production. Algae for biofuels and energy. Springer, New York, pp. 153-163

El Halouani H, Picot B, Casellas C, Pena G, Bontoux J (1993) Elimination de l'azote et du phosphore dans un lagunage à haut rendement. Revue des Sciences de l'Eau 6:47-61

Fernández I, Acién FG, Berenguel M, Guzmán JL, Andrade GA, Pagano DJ (2014) A lumped parameter chemical-physical model for tubular photobioreactors. Chem Eng Sci 112:116-129

Frank MJW, Kuipers JAM, van Swaaij WPM (1996) Diffusion coefficients and viscosities of $\mathrm{CO}_{2}+\mathrm{H}_{2} \mathrm{O}, \mathrm{CO}_{2}+\mathrm{CH}_{3} \mathrm{OH}, \mathrm{NH}_{3}+\mathrm{H}_{2} \mathrm{O}$, and $\mathrm{NH}_{3}+\mathrm{CH}_{3} \mathrm{OH}$ liquid mixtures. J Chem Eng Data 41(2):297302. https://doi.org/10.1021/je950157k

García J, Mujeriego R, Hernández Mariné M (2000) High rate algal pond operating strategies for urban wastewater nitrogen removal. J Appl Phycol 12:331-339

García J, Green BF, Lundquist T, Mujeriego R, Hernández-Mariné M, Oswald WJ (2006) Long term diurnal variations in contaminant removal in high rate ponds treating urban wastewater. Bioresour Technol 97:1709-1715

Gujer W, Henze M, Mino T, Van Loosdrecht M (1999) Activated sludge model no. 3. Water Sci Technol 39(1):183-193

Henze M, Gujer W, Mino T, van Loosdrecht M (2000) Activated sludge models ASM1, ASM2, ASM2d and ASM3. IWA Scientific and Technical Report n. 9, IWA Publishing, London

Khorsandi H, Alizadeh R, Tosinejad H, Porghaffar H (2014) Analysis of nitrogenous and algal oxygen demand in effluent from a system of aerated lagoons followed by polishing pond. Water Sci Technol 70(1):95-101

Krasnits E, Friedler E, Sabbah I, Beliavski M, Tarre S, Green M (2009) Spatial distribution of major microbial groups in a well-established constructed wetland treating municipal wastewater. Ecol Eng 35(7): 1085-1089

Laliberte G, Lessard P, Delanoue J, Sylvestre S (1997) Effect of phosphorus addition on nutrient removal from wastewater with the cyanobacterium Phormidium bohneri. Bioresour Technol 59:227-233

Langergraber G, Rousseau D, García J, Mena J (2009) CWM1: a general model to describe biokinetic processes in subsurface flow constructed wetlands. Water Sci Technol 59(9):1687-1697

Larsdotter K (2006) Wastewater treatment with microalgae-a literature review. Vatten:31-38

Lundquist TJ, Woertz IC, Quinn NWT, Benemann JR (2010) A realistic technological and economic assessment of algae biofuels. Report prepared for the BP Energy Biosciences Institute, Berkeley, California, p 154
Molina Grima E, García Camacho F, Sánchez Pérez JA, Fernández Sevilla J, Acíen Fernandez FG, Contreras Gómez A (1994) A mathematical model of microalgae growth in light limited chemostat cultures. J Chem Technol Biotechnol 61:167-173

Novak JT, Brune DE (1985) Inorganic carbon limited growth kinetics of some freshwater algae. Water Res 19:215-225

Oswald WJ (1988) Microalgal biotechnology. Borowitzka, M.A., Borowitzka, L.J (eds). Cambridge University Press

Park JBK, Craggs RJ (2010) Wastewater treatment and algal production in high rate algal ponds with carbon dioxide addition. Water Sci Technol 61(3):633-639

Park JBK, Craggs RJ, Shilton AN (2011) Wastewater treatment high rate algal ponds for biofuel production. Bioresour Technol 102:35-42

Pereira R, Yarish C, Sousa-Pinto I (2006) The influence of stocking density, light and temperature on the growth, production and nutrient removal capacity of Porphyra dioica (Bangiales, Rhodophyta). Aquaculture 252:66-78

Posadas E, Morales M, Gomez C, Acién FG, Muñoz R (2014) Influence of $\mathrm{pH}$ and $\mathrm{CO} 2$ source on the performance of microalgae based secondary domestic wastewater treatment in outdoors pilot raceways. Chem Eng J 265:239-248

Reichert P, Borchardt D, Henze M, Rauch W, Shanahan P, Somlyódy L, Vanrolleghem P (2001) River water quality model no. 1 (RWQM1): II. Biochemical process equations. Water Sci Technol : J Int Assoc Water Pollut Res 43(5):11-30

Rice EW, Baird RB, Eaton AD 2017Standard methods for the examination of water and wastewater, 23rd Edition. American Public Health Association, American Water Works Association, Water Environment Federation,

Sah L, Rousseau D, Hooijmans CM, Lens P (2011) 3D model for a secondary facultative pond. Ecol Model 222(9):1592-1603

Sams R, García J (2013) Bacteria distribution and dynamics in constructed wetlands based on modelling results. Sci Total Environ 461-462: $430-440$

Sánchez JF, Fernández JM, Acién FG, Rueda A, Pérez J, Molina E (2008) Influence of culture conditions on the productivity and lutein content of the new strain Scenedesmus almeriensis. Process Biochem 43: 398-405

Saunders BK, Giskle MP (1997) The effects of temperature and light on two algal populations in the temperate sea anemone Anthopleura elegantissima (Brandt, 1835). J Exp Mar Biol Ecol 211:213-224

Shelef G, Moraine R, Oron G (1982) Nutrients removal and recovery in a two-stage high rate algal wastewater treatment system. Water Sci Technol 14:87-100

Silyn-Roberts G, Lewis G (2001) In situ analysis of Nitrosomonas sp. in wastewater treatment wetland biofilms. Water Res 35:2731-2739

Singh SP, Singh P (2015) Effect of temperature and light on the growth of algae species: a review. Renew Sust Energ Rev 50:431-444

Solimeno A, García J (2017) Microalgae-bacteria models evolution: from microalgae steady-state to integrated microalgae-bacteria wastewater treatment models - a comparative review. Sci Total Environ 607 608:1136-1150

Solimeno A, García J (2019) Microalgae and bacteria dynamics in high rate algal ponds based on modelling results: long-term application of BIO_ALGAE model. Sci Total Environ 650:1818-1831

Solimeno A, Samsó R, Uggetti E, Sialve B, Steyer JP, Gabarró A, García J (2015) New mechanistic model to simulate microalgae growth. Algal Res 12:350-358

Solimeno A, Samsó R, García J (2016) Parameter sensitivity analysis of a mechanistic model to simulate microalgae growth. Algal Res 15: 217-223

Solimeno A, Parker L, Lundquist T, García J (2017a) Integral microalgaebacteria model (BIO ALGAE): application to wastewater high rate algal ponds. Sci Total Environ 601-601:646-657 
Solimeno A, Acién FG, García J (2017b) Mechanistic model for design, analysis, operation and control of microalgae cultures: calibration and application to tubular photobioreactors. Algal Res 21:236-246

Spolaore P, Joannis-Cassan C, Duran E, Isambert A (2006) Commercial applications of microalgae. Biosci Bioeng 101:87-96

Suganya T, Varman M, Masjuki HH, Renganathan S (2016) Macroalgae and microalgae as a potential source for commercial applications along with biofuels production: a biorefinery approach. Renew Sust Energ Rev 55:909-941

Sutherland D, Turnbull M, Matthew H, Broady P, Craggs RJ (2014) Effects of two different nutrient loads on microalgal production, nutrient removal and photosynthetic efficiency in pilot-scale wastewater high rate algal ponds. Water Res 66:53-62
Talbot P, Thebault JM, Dauta A, de la Nou J (1991) A comparative study and mathematical modeling of temperature, light and growth of three microalgae potentially useful for wastewater treatment. Water Res 25(4):465-472

Von Sperling M (2007) Waste stabilization ponds. IWA Publishing, London

Wu X, Merchuk J (2001) A model integrating fluid dynamics in photosynthesis and photoinhibition processes. Chem Eng Sci 56:35273538

Publisher's note Springer Nature remains neutral with regard to jurisdictional claims in published maps and institutional affiliations. 